\title{
Evaluation of Green IT Services with Fuzzy Screening Approach
}

Sajjad Shokouhyar

Shahid Beheshti University

Iran

\author{
Alireza Noorbakhsh \\ Politecnico di Milano \\ Italy
}

\author{
Armin Aalirezaei \\ Semnan University \\ a.aalirezaei@semnan.ac.ir
}

\section{Abstract}

Regarding development of Information Technology, the world of industry has inordinately benefited, albeit that has some losses. Unless the losses are considered, advanced losses will be seen after progress with which is more difficult to cope. Neglecting the future and the risk involved in the industry, not to mention the lack of knowledge in dealing with sudden alterations, compel irrecoverable loss. In this context, information technology services in organizations are aimed to be cost-effective and have minimum environmental impact, according to green information technology strategies. Concerning significance of the issue, purpose of this research is assessment of information technology services with respect to greenness level in a general contractor organization by combination of Fuzzy Analytic Hierarchy Process and Fuzzy Screening Procedure to enhance the greenness level of IT services. The effectiveness of using this approach is including qualitative, quantitative, and uncertainty nature of the problem. In this paper, to consider the Green IT services criteria, literatures have been studied by meta-synthesis method, then the importance of the criteria has been determined by questionnaires so as to rank Green IT criteria. Eventually, the organization level has been concluded in terms of the greenness level of IT services. As a case study, IT experts and managers of KAYSON Inc. organization are considered as statistical population of this research. The reduction had the highest weight among other criteriarecycling and reusing - in KAYSON Inc. organization. Finally, the organization greenness level was determined moderate in terms of IT services.

Keywords: Green information technology, Fuzzy Screening, Fuzzy Analytic Hierarchy Process

\section{Introduction}

Regarding the fact that every industry which enters the economy cycle of country has inordinate advantages, if the disadvantages of this industry are not considered, after its considerable spread, the damages and harms will undesirably increase. In this case, Information Technology (IT) has a wide array of negative impacts on vital global systems such as energy and economic systems (Moyer \& Hughes, 2012).

Hilty et al. (2006) also support this view by stating that the production, use, and disposal of IT have a direct effect on the natural environment and eco-sustainability. The adverse impact of IT infrastructure is reflected by the escalating size of carbon footprints. Estimates indicate that the IT industry accounts for $2 \%$ of global $\mathrm{CO} 2$ emissions, which is equivalent to the amount generated by the aviation industry (Goasduff \& Forsling, 2007). This phenomenon translates to the rise of global temperature and may affect rapid loss of biodiversity, due to poorly designed systems, obsolete technologies and uninformed behaviour (Jenkin et al., 2011a). Correspondingly, the operating expenditures of IT equipment rise as much as 20 per cent annually, significantly outpacing the annual increase of overall IT spending, which is 6 per cent 
(Gordon et al., 2009). Green IT refers to the using of IT resources in an energy-efficient and cost-effective manner (Bose \& Luo., 2011), and it is foreseen as the most important strategic technology in the imminent future. Organizations are now actively pursuing Green IT solutions for a multitude of reasons and benefits, Including lower power consumption, lower costs, lower carbon emissions, less environmental impact, improved system performance, increased collaboration and interaction amid constituents, space savings, and an agile workforce (Bose \& Luo., 2011).

According to Siegler and Gaughan (2008), Green IT is attributed to the initiatives and programs that address environmental sustainability. It also addresses energy consumption as well as waste associated with the use of hardware and software which tends to have a direct and positive impact (Jenkin et al., 2011b).

Using Green IT services is applicable on condition that the managers of different parts of the organization have a fundamental planning so that the organization would be equipped with IT equipment which consume minimum energy. Not only should plan use such IT equipment, but it also coordinates both human resources and other parts of the organization to optimally use mentioned equipment. Thus, the organization can move towards playing the managerial role of Green IT services by optimal energy consumption and cost reduction which in turns enhance industry, economy, environment, and the competition in global markets (Ruth, 2009).

Now, the question is how managers can comprehend the greenness level of IT services in their company. It is under discussion that which criteria of Green IT are suitable to achieve a fundamental planning for each part of the organization based on the equipment and human resources and which methods are used to manage them. When the importance of criteria is determined, managers utilizing a practical model can conceive the greenness level of the organization IT services and make the right decisions in order to save energy and reduce energy costs. The proposed framework in this research develops a useful model for making decisions to address discussed issue. The objective of this paper is measuring the greenness level of IT services in a general contractor company by the approach of rating the effective criteria as to Green IT in an organization.

The rest of the paper is organized in five sections. The following section reviews background of literature on Green IT and its criteria. Section three develops the research model and questions. The case study, along with data and empirical findings are described in the fourth and the fifth sections respectively. After discussing the main findings in the fifth section, the sixth section highlights the main conclusion and charts avenue for future research.

\section{Literature Review}

The first time the term "Green IT" appeared was 2007 in CIO Magazine (Overby, 2007). Green IT is a systematic application of environmental sustainability criteria to the design, production, sourcing, use and disposal of the IT technical infrastructure as well as within the human and managerial components of the IT infrastructure in order to reduce IT, business process and supply chain related emissions and waste and improve energy efficiency (Molla et al., 2009). Although practitioners have begun to focus on 'Green IT', there is little research in this area. In the face of ever-increasing energy costs, researchers, practitioners, and governments are now seeking effectively initiatives to regulate inefficient energy use by global business enterprises. For example, the UK government aims at decreasing greenhouse gas by $20 \%$ before 2020 (Capra and Merlo, 2009). The combination of the eco-sustainability and the IT infrastructure perspectives can offer useful insight in conceptualizing Green IT. As more organizations become concerned with Green IT, there is a need to understand their capability for implementing and sustaining Green IT strategies and polices. (Mines. 2008). Green IT Policy encompasses the frameworks an organization puts in place to apply environmental criteria in its IT related activities. It measures the extent to which Green issues are encapsulated in organizational procedures guiding the sourcing, use and disposal of the IT technical infrastructure and the activities of the IT human infrastructure (Goasduff \& Forsling, 2007; Info Tech 2007a, 2007b, 2008; Olson, 2008). 
Bose \& Luo (2011) attempt to develop a theoretical framework that illustrate how business transformation via virtualization may assist organizations assess their potential to undertake Green IT initiatives. They develop an integrative framework by synthesizing three information system (IS) theories: (a) technology-organization-environment, (b) process-virtualization, and (c) diffusion of innovation. Using the resource-based view as the theoretical foundation, Dao et al (2011) develop an integrated sustainability framework, illustrating the integration of human, supply chain, and IT resources to enable firms develop sustainability capabilities, which help them deliver sustainable values to relevant stakeholders and gain sustained competitive advantage. Particularly, the role of automate, informate, transform, and infrastructure IT resources are examined in the development of sustainability capabilities. Jenkin et al (2011) develop a multilevel Green IT/S research framework by placing the fragmented Green IT/S literature in conversation with environmental sustainability literatures in management, environmental psychology, and social marketing. Molla et al (2011) report a Green IT Readiness framework to capture the input, transformational and output capabilities that organizations need to nurture in sustainable management of IT. It identifies five components of Green IT readiness (G-readiness) and provides an exploratory framework and a research-ready instrument.

Uddin et al (2012) propose a Green IT framework using virtualization technology to achieve power and energy efficiency in data centres. The framework highlights the importance of implementing green metrics like Power Usage Effectiveness (PUE) and data centre effectiveness, and carbon emission calculator to measure the efficiency of data centre in terms of energy utilization and carbon dioxide (CO2) emissions. Uddin and Rahman (2012) introduce a framework uses latest energy saving techniques like virtualization, cloud computing and green metrics to achieve greener data centres. Green metrics like Power Usage Effectiveness, Data Center Effectiveness and Carbon Emission Calculator to measure performance of individual components have been applied to the proposed framework so that benchmarking values can be achieved and set as standard to be followed.

Bai and Sarkis (2013) present grey-based fuzzy TOPSIS as a generalized method to strategically evaluate and justify, based on multiple sustainability factors, a Green and Sustainable Information Technology, specifically a green data centre design. Wang et al (2015) develop a multi theoretical framework to provide a holistic understanding of the process of implementing and adopting green IS initiatives. The proposed framework examines how these initiatives' structures, organizational attributes, and environment may influence this process.

Thomas et al (2015) find explaining the adoption of Green IT. They evaluate the adoption stages of Green IT. They validate that the pre-adoption stage (Green IT initialization) influences the formal stage of adoption (Green IT integration) and, its integration into the firm's value chain activities (Green IT maturation). Dolci et al (2015) also provides empirical experiences and characteristics of organizations that adopt Green IT practices. Their adopted theoretical framework emphasized IT teams' role in institutionalizing the environmental dimension of sustainability in organizations. The framework tried to interrelate technology, people, and organizations' institutional properties. They show the adoption of more flexible green technologies depends on the users' acceptance so as to become institutionalized.

Addition to above study, literatures are scrutinized on Green IT criteria by meta-synthesis method (Jensen \& Allen, 1996) with the aim of developing a comprehensive list of Green IT criteria.

Each mentioned model in literature has endeavoured to assess the IT greenness level of an organization separately in either qualitative or quantitative point of view, whereas to grasp greenness level of IT services it is required to assess in both qualitative and quantitative aspects.

As regards above literature, a framework measuring both qualitative and quantitative Green IT criteria based on their influence on greenness of IT services has not been yet provided. The contribution of this paper, given all presented criteria in the literature, is now providing a comprehensive model containing the criteria. With such a businesslike framework, general 
contractor organizations can determine their current IT performance with respect to Green IT initiatives (Greenness level of IT services). Presented objectives will be achieved by means of combining Fuzzy Analytic Hierarchy Process (FAHP) and Fuzzy Screening Procedure (FSP) since the former ranks multiple criteria and the latter determines the level of greenness. Finally, according to obtained greenness level of IT services, conscious decisions will be made with respect to related criteria with aim of enhancing level of sustainability. Based on the literature, a comprehensive list of Green IT services criteria was compiled in Table 1.

\begin{tabular}{|c|c|}
\hline Criteria & Reference \\
\hline reduction & $\begin{array}{l}\text { (Dao et al.,2011_; Mithas et al.,2010 ; Akman \& } \\
\text { Mishra,2015) }\end{array}$ \\
\hline recycling & (Olson.,2008; Mithas et al.,2010) \\
\hline reuse & (Bose \& Luo., 2011_; Fernando,2015) \\
\hline The use of backup power system & (Gan et al., 2007_; Kant,2009) \\
\hline The use of Data Center Model & (Kipp et al., 2012; Peng,2013) \\
\hline $\begin{array}{l}\text { Designing appropriate cooling system } \\
\text { in data centers }\end{array}$ & (Sharma.S \& Sharma.G, 2016) \\
\hline Virtualizing server and desktop & (Tomlinson ,2010; Olzak et al.,2010 ; Bose \& Luo., 2011) \\
\hline Composing server's structure & (Norton.,1996) \\
\hline The use of more Internet access & (Tomlinson ,2010; Manju et al., 2014) \\
\hline $\begin{array}{l}\text { Buying environmentally compatible } \\
\text { technologies }\end{array}$ & $\begin{array}{l}\text { (Tomlinson ,2010; Höjer\& Wintzell., } 2012 \text {; Zelenika \& } \\
\text { Pearce, 2014) }\end{array}$ \\
\hline $\begin{array}{l}\text { Buying modern information } \\
\text { technologies }\end{array}$ & $\begin{array}{l}\text { (Mansell \& When.,1998 ; Tomlinson ,2010 ; Davidson et } \\
\text { al.,2011) }\end{array}$ \\
\hline $\begin{array}{l}\text { The use of office automation software } \\
\text { system }\end{array}$ & (Zhang et al., 2003; Uddin et al.,2015) \\
\hline The use of video conferencing & (Molla \& Abareshi,2012 ; Hedman \& Henningsson.,2016) \\
\hline $\begin{array}{l}\text { Energy management of personal } \\
\text { computers }\end{array}$ & $\begin{array}{l}\text { (Affanni et al., } 2005 \text {; Tomlinson ,2010 ; Ozturk et al., } \\
\text { 2011) }\end{array}$ \\
\hline Implementing telework & (Anthony \& Majid ,2016; Hynes , 2013) \\
\hline $\begin{array}{l}\text { Asset disposal to Include IT equipment } \\
\text { recycling }\end{array}$ & (Bose \& Luo., 2011) \\
\hline Management of recycling system & $\begin{array}{l}\text { (Simmonds \& Bhattacherjee ,2012 ; Fitzsimmons et al., } \\
\text { 2013) }\end{array}$ \\
\hline $\begin{array}{l}\text { The recycle information technology } \\
\text { equipment }\end{array}$ & (Choi et al., 2006 ; Sinha,2011) \\
\hline Sustainable packaging & $\begin{array}{l}\text { (Tomlinson ,2010 ; Frehe \& Teuteberg, } 2014 \text {; Dubey et } \\
\text { al,2015) }\end{array}$ \\
\hline Product redesign & $\begin{array}{l}\text { (Porter \& Van der Linde., } 1996 \text {; Wolf et al.,2012 ; } \\
\text { Mysore,2012) }\end{array}$ \\
\hline Cost of new product assembly & (Bramorski et al., 2000 ; Kalpakjian \& Schmid., 2006 ) \\
\hline Sustainable design & (Tomlinson ,2010 ; Jenkin et al., 2011 ; Garbie, 2016) \\
\hline Remanufacture & (Putri \& Hudirarto.,2015) \\
\hline
\end{tabular}

Table 1-Comprehensive list of Green IT criteria

\section{Method}

The research method used literature review, questionnaire assessment and case study. Firstly, literature of Green IT criteria and their impacts on IT services sector have been studied by 
meta-synthesis method (Erwin et al., 2011). Considering keywords "green information technology" and "criteria" 518 articles was found through online data sources, then the search was narrowed down in accordance with relevant abstract, content, title. Consequently, 42 papers were found by the end of year 2016. Secondly, after extracting criteria from the final stage of meta-synthesis method, questions have been designed according to gathered criteria (Table 1) by the authors, then questionnaires were distributed between experts of KAYSON Inc. as a general contractor. At the end, by utilizing a combination method of Fuzzy AHP and screening the greenness level of IT services in the general contractor organization was defined. Figure 1 shows the Schematic form of the research methodology.

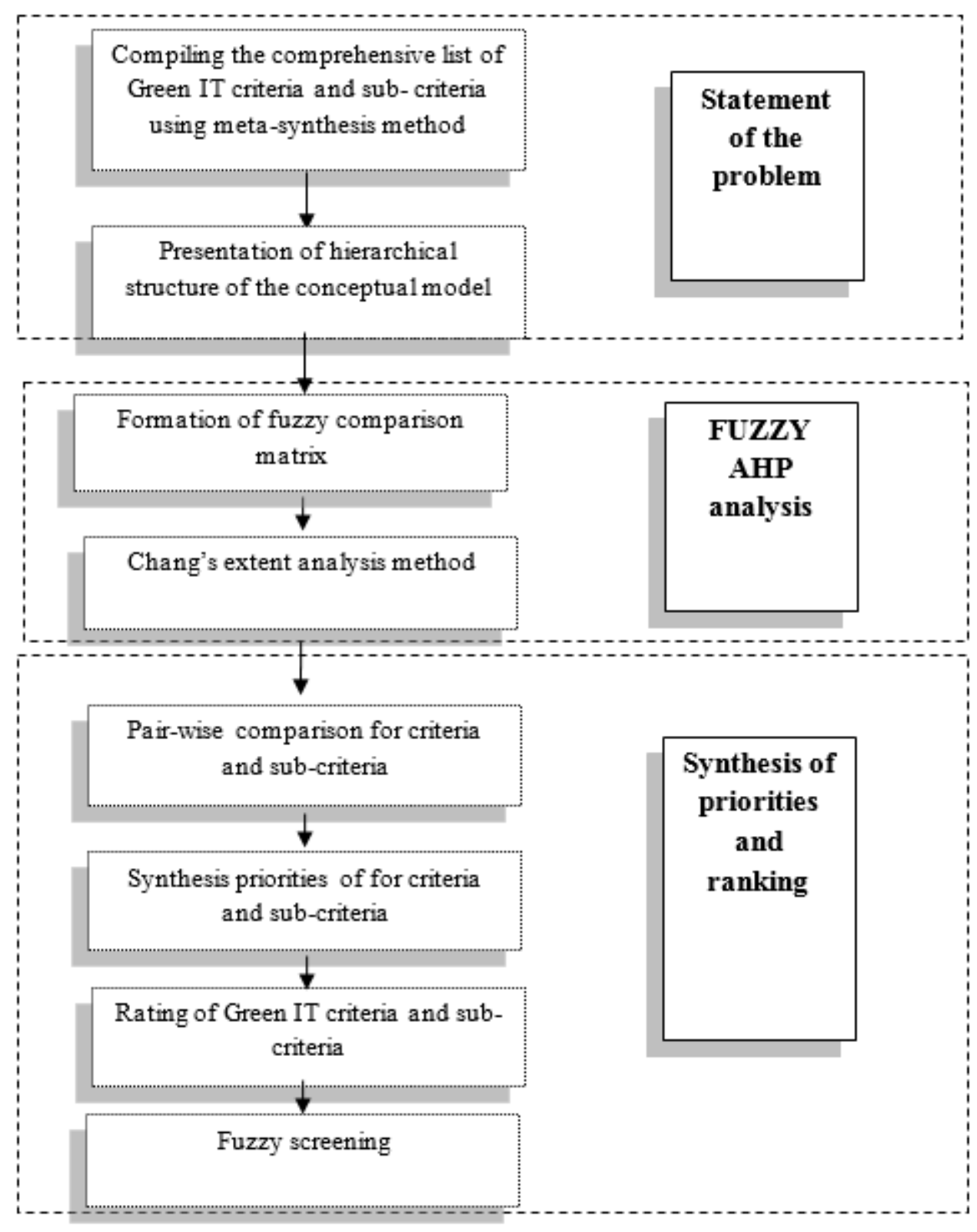

Figure 1- The Schematic of research methodology

\subsection{Hierarchical structure of the conceptual model}

In the hierarchical structure of the conceptual model, based on criteria relationships obtained from meta-synthesis method, all of criteria mentioned in Table 1 were categorized into three major criteria- reduction, recycling, and reuse- as shown in Figure 2. 


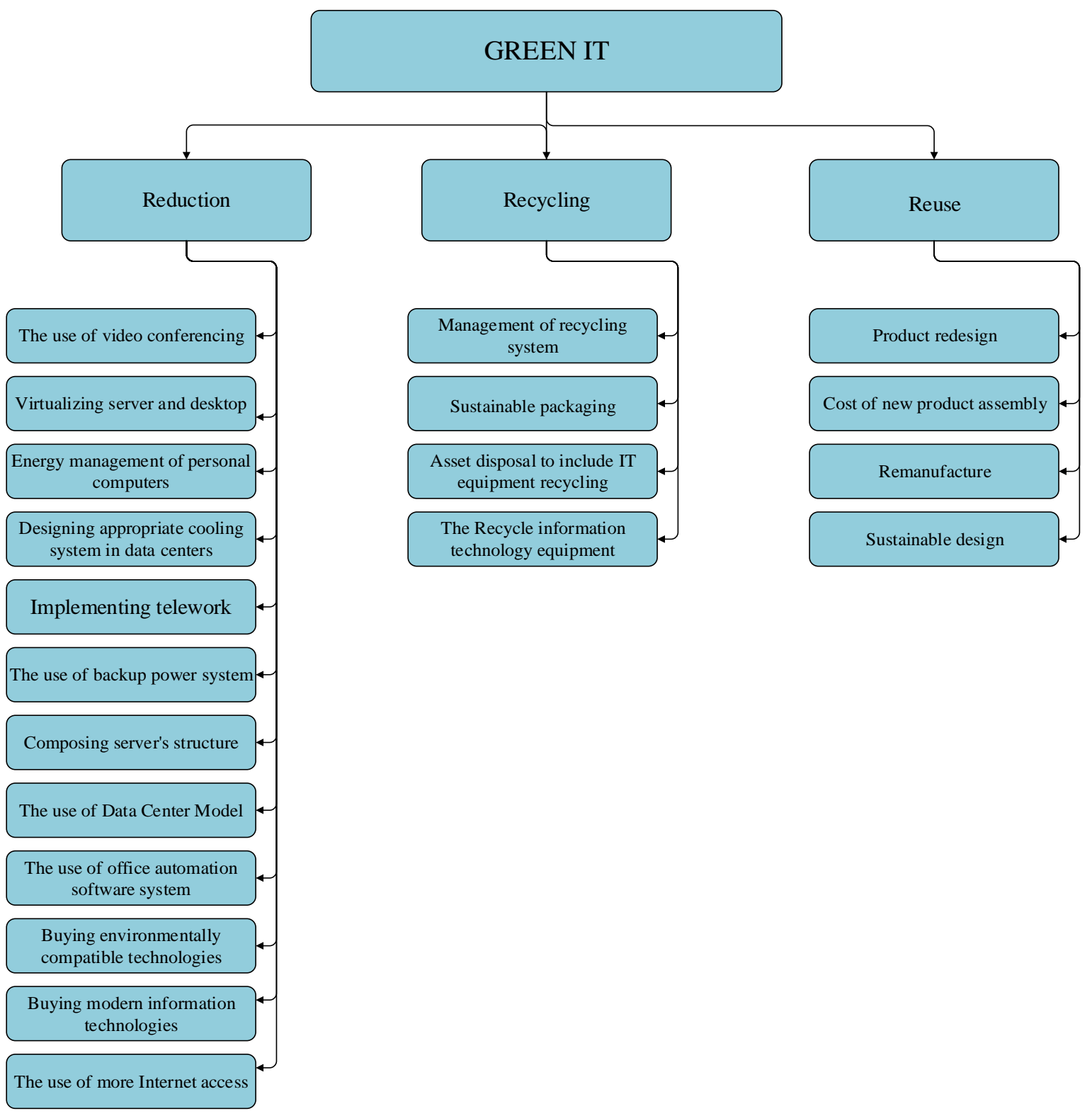

\section{Figure 2- hierarchical structure of the conceptual model}

In the hierarchical structure of the proposed model, the purpose is located in the first level. In the second level and the third level, the main criteria and sub criteria are located respectively. Regarding significance of the issue, the purpose of the research model is assessment of IT services by Fuzzy Screening to enhance greenness level of a general contractor organization. In this plan, the problem is solved by means of a two-phased methodology. In the first phase, AHP approach is used so that evaluating organization in respect of Green IT criteria and subcriteria. To do this, two questionnaires determined the importance of criteria and weight of them were token to reporters of the IT department. An AHP method is used for the aims of approaching the priority set of criteria concerning Green IT services objectives. In the second phase, assessment of IT services is applied by Fuzzy Screening to calculate and enhance the greenness level of organization. Using the developed methodology will eventually result in a ranking of IT services criteria that makes it possible for decision makers to select the most suitable service(s) concerning Green objectives in organizations.

\subsection{Fuzzy AHP}

The Fuzzy AHP method is to combine the hierarchy analysis with the fuzzy set theory, and add the triangular fuzzy function into the pair-wise comparison matrix to obtain the fuzzy weight 
values of various objects (Buckley, 1985). It will avoid having extreme subjective perception and uncertainty. Regarding fuzzy approach, linguistic variables and fuzzy numbers have been used as shown in Table 2.

The steps of Fuzzy AHP method follow (Chang, 2004). First, through the survey of experts, the relative importance level of each pair of factors can be obtained with pair-wise comparison matrix. To integrate the experts' opinions, Saaty (1980) suggested taking the 'geometric mean' as the integration value. The pair-wise comparison Matrix $\tilde{A}_{i}$ is shown below.

$\tilde{A}_{i}=\left[\begin{array}{cccc}1 & \tilde{a}_{12} & \cdots & \tilde{a}_{1 n} \\ \tilde{a}_{21} & 1 & \cdots & \tilde{a}_{2 n} \\ \vdots & \vdots & \ddots & \vdots \\ \tilde{a}_{n 1} & \tilde{a}_{n 2} & \cdots & 1\end{array}\right]$

$\tilde{a}_{i j}=\left(L_{i j}, M_{i j}, U_{i j}\right)$

$\tilde{a}_{i j} * \tilde{a}_{j i} \approx 1, \forall \mathrm{i}, \mathrm{j}=1,2, \ldots, \mathrm{n}$

Where $L_{i j}, M_{i j}, U_{i j}$ are the left value, middle value, right value of the triangular fuzzy function that represents the relative importance level of factor $i$ to factor $j$, respectively.

The second step is to verify the consistency for pair-wise comparison matrix and delete those that do not fit the qualification.

The third step is to calculate the fuzzy weight on every row of the fuzzy positive reciprocal matrix, $\widetilde{w}_{i}$ as follows:

$\tilde{Z}_{i}=\left[\tilde{a}_{i 1} \otimes \ldots \otimes \tilde{a}_{i n}\right]^{\frac{1}{n}}, \quad \forall \mathrm{i}=1,2, \ldots, \mathrm{n}$

$\widetilde{w}_{i}=\tilde{Z}_{i} \otimes\left(\tilde{Z}_{1} \oplus \tilde{Z}_{2} \oplus \ldots \oplus \tilde{Z}_{n}\right)^{-1}$

Where $\tilde{Z}_{i}$ is the geometric mean of triangular fuzzy number; $\tilde{a}_{i j}$ is the triangular fuzzy number located on row $i$ and column $j$ of the fuzzy positive reciprocal matrix.

The fourth step is to use weighted method to Defuzzy the triangular fuzzy number, and obtain the best non-fuzzy value or crisp value. The calculation is shown below.

$D F W_{i}=\frac{\left[\left(U_{i}-L_{i}\right)+\left(M_{i}-L_{i}\right)\right]}{3}+L_{i}$

The fifth step is to standardize the weight value obtained for every factor, and make it a unique crisp value.

$W_{i}=\frac{D F W_{i}}{\sum D F W_{i}}$

Finally, if $\tilde{f}_{j}=\left(\tilde{f}_{j 1}, \ldots, \tilde{f}_{j k}\right)$ is the fuzzy weight of every factor $A_{j}$, and $\tilde{e}=\left(\tilde{e}_{1}, \ldots ., \tilde{e}_{k}\right)$ is the fuzzy weight of the upper level $\mathrm{E}$, then the weight of every factor is shown as follows:

$\widetilde{w}_{j}=\left(\tilde{f}_{j 1} \otimes \tilde{e}_{1}\right) \oplus \ldots \oplus\left(\tilde{f}_{j k} \otimes \tilde{e}_{k}\right)$

\begin{tabular}{|c|c|c|}
\hline Fuzzy Triangular Scale & Linguistic Scale & Code \\
\hline$(1,1,1)$ & Just Equal & 1 \\
\hline$(0.5,1,1.5)$ & Equal Important & 2 \\
\hline$(1,1.5,2)$ & Weakly More important & 3 \\
\hline$(1.5,2,2.5)$ & Strongly More Important & 4 \\
\hline$(2,2.5,3)$ & Very Strongly More Important & 5 \\
\hline$(2.5,3,3.5)$ & Absolutely More Important & 6 \\
\hline$(3,3.5,4)$ & Extremely important & 7 \\
\hline
\end{tabular}

Table 2- Linguistic variables and fuzzy numbers 


\subsection{Fuzzy screening}

The FSP is useful for the selection of a small subset of alternatives from much larger set of alternatives (Carlsson \& Fullér, 1995). Each alternative is described by minimal information. The process involves multiple criteria attributes used for alternative description, as well as multiple experts whose opinion must be considered. Therefore, fuzzy screening procedure (FSP) is usually considered as a Multi Expert - Multi Criteria procedure. The FSP is of following steps: (Stojanov et al., 2013)

Step 1: Formation of Matrix ( $\pi$ ); Each expert for each alternative gives his/her opinion (score) how well that alternative satisfies each of the criteria. For this process, the scale $\mathrm{S}$ of $\mathrm{m}$ elements is used.

Formation of Matrix (I); independently, each expert should provide an opinion on how important is each criteria attribute; this is done by using the same scale $\mathrm{S}$.

Step 2: Very important is the definition of the negation for the scale $S$ according to the equation (6):

$\operatorname{Neg}\left(S_{i}\right)=S_{m-i+1}$ and $\mathrm{i}=1,2, \ldots, \mathrm{m}$

Step 3: According to the equation (7), the integration of $\mathrm{Neg}(\mathrm{I})$ and $\pi$ is achieved and then its minimum is taken for each expert.

$U_{i k}=\min _{j}\left\{\operatorname{Neg}\left(I_{k j}\right) v \pi_{i j k}\right\}$, and $\mathrm{k}=1,2, \ldots, \mathrm{r}, \mathrm{j}=1,2, \ldots, \mathrm{h}$

k: experts, j: sub-criteria

Step 4: Sorting elements obtained in step 3 according descending order.

Step 5: After this stage of the process, each expert evaluates each alternative. If there are $r$ experts, then for each alternative is associated $r$ scores. Further process is an aggregation of scores in order to obtain overall score for each alternative. There are many aggregation operators, but in this case, Ordered Weighted Averaging operator (OWA) proposed by Yager (Yager, 1994; Detyniecki, 2001) is used.

The step 5 in the process is definition of the aggregation function Q. As in Carlsson and Fullér, (1995) "This function can be seen as a generalization of the idea of how many experts it feels need to agree on an alternative for it to be acceptable to pass the screening process". Besides some trivial, as well as more complex definitions of $\mathrm{Q}$, the function which emulates the average is denoted as $\mathrm{Q}(\mathrm{k})$ :

$\mathrm{Q}(\mathrm{k})=S_{b(k)}$

$b(k)=\operatorname{int}\left[1+\frac{k(q-1)}{r}\right]$

In Eq. (9) Int [a] returns a value that is the closest to a, q is number of points on the scale and $r$ is the number of experts.

Step 6: An OWA operator of dimension $\mathrm{n}$ is a mapping F: $R^{n} \rightarrow R$ that has associated vector: $\mathrm{w}=\left(w_{1}, \ldots, w_{n}\right)^{T}$, where $w_{i} \in[0,1], 1 \leq i \leq n$. Furthermore:

$\sum_{i=1}^{n} w_{i}=1$, and $\mathrm{F}\left(a_{1}, \ldots, a_{n}\right)=\sum_{i=1}^{n} w_{j} b_{j}$,

Where $b_{j}$ is the $\mathrm{j}$-th largest element of the bag $\left\langle a_{1}, \ldots, a_{n}\right\rangle$.

After appropriately selected Q, it is possible to use the OWA method for aggregating experts' opinions. The overall score A for an alternative is calculated by Eq. (10):

$\mathrm{A}=\max _{j}\left\{Q_{j} \wedge B_{j}\right\}$

In Eq. (10) $b_{j}$ is the worst of the j-th top scores. 


\section{Case study: IT experts and managers of KAYSON Inc. organization}

Founded in 1975, KAYSON Inc. is an international general contractor company providing premier management, engineering, procurement, construction, financing and investment services worldwide. The organizational structure of KAYSON Inc. has been designed that every project enjoys a unified chain of project management steps. A network of specialized technical, engineering, logistics and supporting units feed the projects. (KAYSON Inc., 2016) Coordinating these units, IT plays a key role in KAYSON Inc. Not only is KAYSON Inc. -general contractor-committed to safeguarding the health and safety of its staff and other stakeholders, but it is also committed to protect the environment. To achieve the goal of augmenting the positive environmental impact, Green IT as a practical means should be considered. Therefore, much needs to be done by KAYSON Inc. with the aim of adjusting its organizational units to applying Green IT services. As known, testing the validity of a proposed or developed model is an extremely important issue. In this study, the issue of validity of the proposed AHP model is considered. The model's validity, reliability, and generalizability have assessed as following: a) Variables have extracted from literature validated from pervious researches, b) Application of the model is developed with the aim of assessing greenness level of IT services in general contractor organizations. In addition, the model is implemented and approved as an applicable model in KAYSON. Inc. as a general contractor by its executives expertise. Therefore, the model has validity, reliability, and generalizability for assessing similar general contradictors.

The developed model is applied so as to enhance the greenness level of IT services. IT experts and managers of KAYSON Inc. organization are population of this research.

\subsection{Result and Discussion}

The next step of the paper is to conduct surveys with the five experts from IT sector of KAYSON Inc. Inc. in order to verify the model. Three types of Questioners designed in order to obtain weights, importance, and presently state of the criteria have been designed for the survey. Detailed results are presented as follows:

\subsubsection{The hierarchy of the assessment}

The whole hierarchy of the assessment can be easily visualized in Figure 3. It involves three levels. The goal is to evaluate greenness IT service level of the KAYSON Inc. In the second level, there are three assessment areas: reduction, recycling, and reuse. Eventually, there are a number of sub-criteria under these three major criteria.

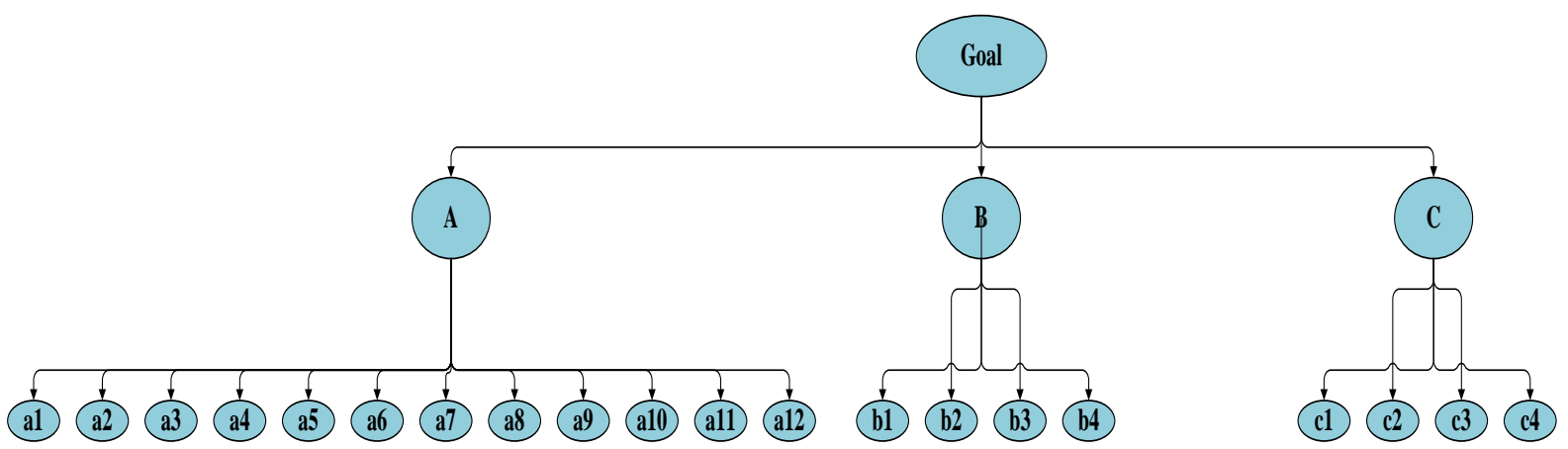

Figure 3 - The Schematic hierarchy of the assessment

The relative importance of each Green IT criteria and sub-criteria at a specific level are measured by a procedure of pairwise comparison (see Appendix). The decision makers provide fuzzy weights for the priority of each criteria by using a rating scale (Table 2). The process is repeated for each level of the hierarchy until a decision is finally reached by overall composite weights. The last step is to use equations $(3,4$, and 5$)$ to obtain the non-fuzzy value. Table 3 presents the overall weighting information for each element in the AHP model. By synthesizing the experts' opinions with the priorities, the ratings of the green sub-criteria in respect of the 
end and synthesized priorities for each sub-criterion have been obtained. The final ranking of criteria and sub-criteria are depicted respectively in Figures 4 and 5 .

\begin{tabular}{|l|l|l|c|}
\hline $\begin{array}{c}\text { Criteria } \\
\text { symbol }\end{array}$ & \multicolumn{1}{|c|}{ Criteria Name } & \multicolumn{1}{|c|}{$\begin{array}{c}\text { Normalized } \\
\text { Fuzzy Weight }\end{array}$} & $\begin{array}{c}\text { Non- } \\
\text { Fuzzy } \\
\text { Weight }\end{array}$ \\
\hline A & Reduction & $(0.379,0.536,0.728)$ & 0.545 \\
\hline a.1 & The use of backup power system & $(0.065,0.125,0.219)$ & 0.08 \\
\hline a.2 & The use of Data Center Model & $(0.062,0.122,0.216)$ & 0.078 \\
\hline a.3 & Designing appropriate cooling system in data centers & $(0.045,0.092,0.17)$ & 0.06 \\
\hline a.4 & Virtualizing server and desktop & $(0.05,0.096,0.174)$ & 0.062 \\
\hline a.5 & Composing server's structure & $(0.048,0.092,0.175)$ & 0.061 \\
\hline a.6 & The use of more Internet access & $(0.04,0.078,0.15)$ & 0.052 \\
\hline a.7 & Buying environmentally compatible technologies & $(0.039,0.073,0.134)$ & 0.048 \\
\hline a.8 & Buying modern information technologies & $(0.043,0.076,0.139)$ & 0.05 \\
\hline a.9 & The use of office automation software system & $(0.033,0.06,0.115)$ & 0.04 \\
\hline a.10 & The use of video conferencing & $(0.032,0.058,0.112)$ & 0.039 \\
\hline a.11 & Energy management of personal computers & $(0.03,0.054,0.108)$ & 0.037 \\
\hline a.12 & Implementing telework & $(0.038,0.075,0.187)$ & 0.058 \\
\hline B & Recycling & $(0.222,0.306,0.44)$ & 0.318 \\
\hline b.1 & Asset disposal to Include IT equipment recycling & $(0.227,0.354,0.516)$ & 0.123 \\
\hline b.2 & Management of recycling system & $(0.244,0.332,0.465)$ & 0.116 \\
\hline b.3 & The recycle information technology equipment & $(0.126,0.174,0.245)$ & 0.061 \\
\hline b.4 & Sustainable packaging & $(0.102,0.14,0.204)$ & 0.049 \\
\hline C & Reuse & $(0.12,0.158,0.218)$ & 0.164 \\
\hline c.1 & Product redesign & $(0.255,0.369,0.514)$ & 0.065 \\
\hline c.2 & Cost of new product assembly & $(0.174,0.255,0.366)$ & 0.045 \\
\hline c.3 & Sustainable design & $(0.184,0.254,0.366)$ & 0.046 \\
\hline c.4 & Remanufacture & & 0.022 \\
\hline
\end{tabular}

Table 3 - The overall weighting information for each element in the AHP model

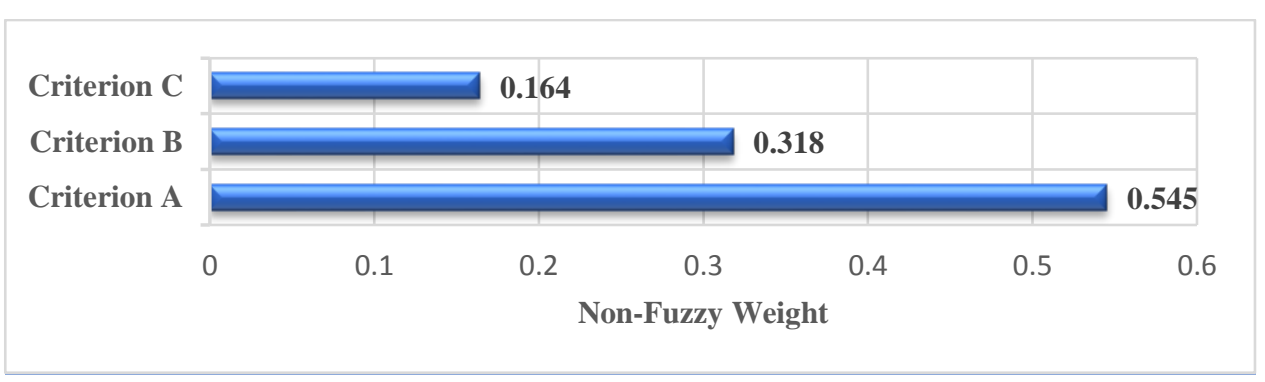

\section{Figure 4- Final ranking of main criteria}

In accordance with Table 3, Figure 4 and 5 in KAYSON Inc., main criteria of reduction of costs and energy has the first priority from the point of experts' view.

Asset disposal Including IT equipment recycling had the highest priority and remanufacture had the lowest priority among the sub-criteria. Among sub-criteria, the criterion of Composing server's structure and the recycle IT equipment have the same priority. 


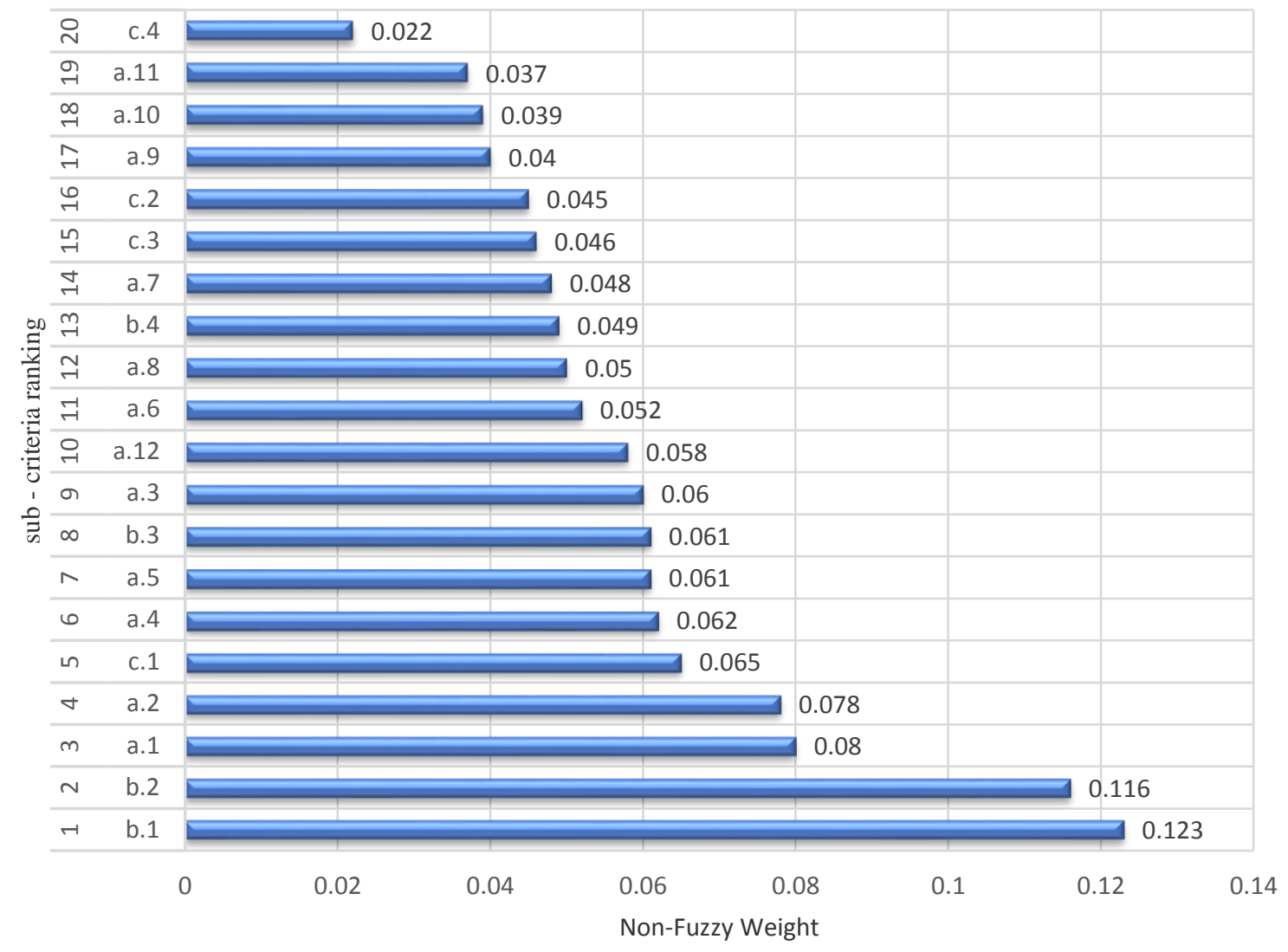

Figure 5- Final ranking of sub criteria

\subsubsection{Results of Fuzzy Screening}

Five men from IT experts and managers of KAYSON Inc. were asked to assign values to assess the importance of attributes selected for judging about how well that alternative satisfies each of the criteria and sub-criteria and how important is each of them attribute. As a sample in point, Tables 4-10 show the result of fuzzy screening process of the reduction criteria (A). Subsequently, greenness level of IT services in KAYSON organization from viewpoint of reduction in cost, energy, and environmental impact has been calculated according to Eq. (6)(10).

\section{Fuzzy screening of the reduction criteria (A):}

To form matrix (I), independently, each expert has provided a judgment on how important is each criteria attribute according to scales of Table 2.

\begin{tabular}{|l|c|c|c|c|c|c|c|c|c|c|}
\hline Matrix I & a.1 & a.2 & a.3 & a.5 & a.6 & a.8 & a.9 & a.10 & a.11 & a.12 \\
\hline Expert 1 & 6 & 5 & 5 & 5 & 4 & 7 & 4 & 3 & 7 & 4 \\
\hline Expert 2 & 6 & 6 & 6 & 5 & 6 & 7 & 5 & 4 & 7 & 4 \\
\hline Expert 3 & 5 & 6 & 5 & 5 & 5 & 6 & 5 & 5 & 6 & 5 \\
\hline Expert 4 & 6 & 5 & 5 & 5 & 6 & 5 & 6 & 5 & 6 & 1 \\
\hline Expert 5 & 5 & 4 & 4 & 5 & 5 & 6 & 4 & 3 & 7 & 5 \\
\hline
\end{tabular}

Table 4-Matrix (I), the importance of reduction sub-criteria according to the experts 
Then, to form matrix $(\pi)$, each expert for each criteria gives his/her score (opinion) of how much that criterion is important as presently it is in KAYSON Inc. For this process, the scale $\mathrm{S}$ of Table 2 is used.

\begin{tabular}{|l|c|c|c|c|c|c|c|c|c|c|}
\hline Matrix $\boldsymbol{\pi}$ & a.1 & a.2 & a.3 & a.5 & a.6 & a.8 & a.9 & a.10 & a.11 & a.12 \\
\hline Expert 1 & 6 & 5 & 6 & 5 & 2 & 4 & 6 & 4 & 6 & 1 \\
\hline Expert 2 & 6 & 5 & 5 & 4 & 6 & 5 & 5 & 4 & 6 & 1 \\
\hline Expert 3 & 6 & 6 & 6 & 5 & 6 & 5 & 5 & 5 & 7 & 1 \\
\hline Expert 4 & 5 & 5 & 5 & 4 & 6 & 5 & 5 & 4 & 6 & 1 \\
\hline Expert 5 & 5 & 4 & 6 & 4 & 5 & 5 & 5 & 4 & 6 & 1 \\
\hline
\end{tabular}

Table 5-Matrix ( $\pi$ ), the score of reduction sub-criteria according to the expert as presently it is

According to the equation (6) in step 2 of fuzzy screening, negation for the matrix (I) is calculated as follow:

\begin{tabular}{|c|c|c|c|c|c|c|c|c|c|c|}
\hline $\boldsymbol{N e g}(I)$ & a.1 & a.2 & a.3 & a.5 & a.6 & a.8 & a.9 & a.10 & a.11 & a.12 \\
\hline Expert 1 & 2 & 3 & 3 & 3 & 4 & 1 & 4 & 5 & 1 & 4 \\
\hline Expert 2 & 2 & 2 & 2 & 3 & 2 & 1 & 3 & 4 & 1 & 4 \\
\hline Expert 3 & 3 & 2 & 3 & 3 & 3 & 2 & 3 & 3 & 2 & 3 \\
\hline Expert 4 & 2 & 3 & 3 & 3 & 2 & 3 & 2 & 3 & 2 & 7 \\
\hline Expert 5 & 3 & 4 & 4 & 3 & 3 & 2 & 4 & 5 & 1 & 3 \\
\hline
\end{tabular}

Table 6- Negation for the scale $S$ of matrix (I)

In the next step, According to the equation (7), the integration of $\operatorname{Neg}(\mathrm{I})$ and $\pi$ is achieved (Table 7) and then its minimum is taken for each expert (Table 8).

\begin{tabular}{|l|c|c|c|c|c|c|c|c|c|c|}
\hline $\begin{array}{l}\text { Matrix } \\
\boldsymbol{N e g}(I) \boldsymbol{v} \pi\end{array}$ & a.1 & a.2 & a.3 & a.5 & a.6 & a.8 & a.9 & a.10 & a.11 & a.12 \\
\hline Expert 1 & 6 & 5 & 6 & 5 & 4 & 4 & 6 & 5 & 6 & 4 \\
\hline Expert 2 & 6 & 5 & 5 & 4 & 6 & 5 & 5 & 4 & 6 & 4 \\
\hline Expert 3 & 6 & 6 & 6 & 5 & 6 & 5 & 5 & 5 & 7 & 3 \\
\hline Expert 4 & 5 & 5 & 5 & 4 & 6 & 5 & 5 & 4 & 6 & 7 \\
\hline Expert 5 & 5 & 4 & 6 & 4 & 5 & 5 & 5 & 5 & 6 & 3 \\
\hline
\end{tabular}

Table 7- Neg(I) $v \pi$

\begin{tabular}{|c|c|}
\hline B & Criteria \\
\hline B11 & 4 \\
\hline B12 & 4 \\
\hline B13 & 4 \\
\hline B14 & 3 \\
\hline B15 & 3 \\
\hline
\end{tabular}

Table 8-Assortment of $\min [\operatorname{Neg}(I) v \pi]$ 
Next step is to aggregate the scores in order to obtain overall score for each criteria. In step 5 of fuzzy screening, based on equation (8) and (9), the results of aggregation function is shown in Table 9:

\begin{tabular}{|ll|}
\hline \multicolumn{2}{|c|}{$\mathrm{B}$} \\
\hline $\mathrm{K}=1$ & $\mathrm{Q}(1)=2$ \\
\hline $\mathrm{K}=2$ & $\mathrm{Q}(2)=3$ \\
\hline $\mathrm{K}=3$ & $\mathrm{Q}(3)=4$ \\
\hline $\mathrm{K}=4$ & $\mathrm{Q}(4)=5$ \\
\hline $\mathrm{K}=5$ & $\mathrm{Q}(5)=7$ \\
\hline
\end{tabular}

Table 9- The aggregation function $(Q)$

The overall score A for a criterion (here reduction) is calculated by Eq. (10). The result is shown in Table 10:

\begin{tabular}{|c|}
\hline $\boldsymbol{Q}(\boldsymbol{j}) \wedge \boldsymbol{B}_{\boldsymbol{i j}}$ \\
\hline 2 \\
\hline 3 \\
\hline 4 \\
\hline 3 \\
\hline 3 \\
\hline
\end{tabular}

Table $10-Q \wedge B$

$A=\max \{2,3,4,3,3\}=4$

Similarly, above steps are repeated for criteria "B" and "C". Eventually, the results of ranking and evaluating of greenness level of IT services in the KAYSON Inc. organization have been presented in Table 11.

\begin{tabular}{|c|c|c|c|}
\hline Criterion C & Criterion B & Criterion A & Company \\
\hline 4 & 4 & 4 & KAYSON Inc. organization \\
\hline
\end{tabular}

Table 11- The results of greenness level of IT services in the KAYSON Inc. organization

According to the fuzzy scales shown in Table 2 and results in Table 11, all three major criteriareduction, recycling, and reuse-are equally "Strongly More Important". In other words, the greenness level of KAYSON Inc. is average in terms of utilizing IT services.

\section{Conclusion}

There is resistance and misunderstanding surrounding Green IT among some managers resulting from a general misunderstanding of the benefits of Green IT. Green IT helps the reduction of environmental impacts resulted from the activity of IT in IT-benefited organizations. Furthermore, such enhanced impacts will be accompanied with lower total costs for companies. The equipment used in this technology are green on condition that they can be either disposed or reused after the end of their lives with minimum possible side effects on environment, in other words, the equipment should be stroke a right balance between probable adverse environmental impacts for used technology and that for available new technology. 
After realizing the importance of green IT in IT-oriented organizations, then the question is how to assist managers of general contractor organizations to comprehend the greenness level of IT services in their company and to make right decisions to save energy and reduce energy costs. This research proposed a framework to address this issue: Firstly, literature of Green IT criteria and their impacts on IT services sector have been studied by meta-synthesis method. A comprehensive list of criteria is created. Secondly, the priority of Green IT criteria has been studied by using Fuzzy AHP approach and then the organization level has been examined in term of the greenness of IT services through Fuzzy screening. Finally, the proposed model has been received its' validity, reliability, and generalizability by implementing it in KAYSON. Inc. as a case study.

The relative ease with which multiple criteria can be handled is one of the main strength of Fuzzy AHP. In addition to this, AHP is easier to understand and it can effectively handle both qualitative and quantitative data (Kahraman \& Ulukan 2003). As the focus of this study is on the indices which measure the greenness level of IT services in general contractor organizations and these quantitative and qualitative indices cannot be exactly measured, Fuzzy AHP method have been used to evaluate them. Furthermore, highly cited studies have proposed modelling with triangular fuzzy numbers as an effective method to formulate decision-making problems where the available information is subjective and inaccurate (Chang \& Yeh, 2002). In this paper, combination of Fuzzy AHP and Fuzzy Screening is preferred in the ranking of organizational green indicators as this method is the only one utilizing a hierarchical structure. Usage of pair-wise comparisons is another advantage of this method that provide precise information about the preferences of decision makers. Furthermore, since the decision-makers are usually unable to explicit about their preferences owing to the fuzzy nature of the decision process, this method helps them providing an ability of giving interval judgments instead of point judgments (Bozbura \& Beskese2007). This could inform decision makers of crucial factors so as to reduce the environmental impacts, not to mention reducing the organization total costs.

As a case study, the model is implemented in KAYSON Inc. which is one of the biggest general contractors in Iran. The major factors of the Green IT services in KAYSON Inc., namely reduction, recovery and reuse, were extracted from the research model, then the questionnaires were completed by IT experts of the Company. The reduction criterion refers to the reduction of energy, cost, and environmental impacts which can be achieved as the result of using the Green IT equipment. The recycling criterion also brings about the reduction of environmental impacts and the reuse criterion is repairing and the fundamental product correction leading to the cost reduction.

The results show that in KAYSON Inc., based upon both Fuzzy AHP analysis and order of weights, reduction is the most preferential option, then recycling and eventually reusing are so. Furthermore, among sub-criteria the highest priority is Asset Disposal Including IT equipment recycling and the lowest priority is remanufacturing. In addition, After fuzzy screening processes, according to the fuzzy scales given in Table 2 and results in Table 11, all three major criteria-reduction, recycling, and reuse-are equally "Strongly More Important". In other words, the greenness level of KAYSON Inc. is moderate in terms of utilizing IT services.

The KAYSON Inc. managers should consider the following solutions according to highest weights in Figure 5, in order to enhance the greenness level of IT services:

Asset disposal to include IT equipment recycling: KAYSON Inc. does disposal IT equipment with none recycling plan. Choosing a waste disposal organization that follows the waste hierarchy to donate KAYSON Inc.'s working equipment and recycle the non-working equipment, in other words, planning and executing Enterprise IT Asset Disposition programs. In the meantime, KAYSON Inc. should store waste equipment safely.

Management of recycling system: KAYSON Inc. does not environmentally take any liability to its IT equipment end of life. Therefore, managing the recycling system from the reduction step, storing and processing, collection and transportation, recycling, dispelling is recommended. Subsequently, consideration and attention after the disposal should be taken into account. 
The use of backup power system: The Backup power systems being used in KAYSON Inc. does not possess an efficient system to support scalability and to provide expected back up timing. The system should have the capability to start with the smaller system and to add another system later on to double up on the available peak power output. Furthermore, recommended system should have the option to select the right amount of power for its needs. To have more green backup system, Hydrogen fuel cell power generators is also recommended in comparison with mechanical power generation or batteries.

The use of Data Centre Model: A major concern for KAYSON Inc. IT department is slow responsiveness to business demands inasmuch as a simple request takes inordinate time to fulfil. As a forward looking company, KAYSON Inc. should use a Data Center model which facilitate virtualization, simplification, automation, and accelerated delivery of cloud applications and services to provide a sustainable business advantage. To resolve the current Data Center Model, the Cisco Unified Data Center platform was designed specifically to overcome the current data centre constraints and provide agile, simplified, and efficient IT service delivery and cloud computing. Cisco Unified fabric, computing, and management.

When IT equipment reach end of their lives, KAYSON Inc. should consider decision models with which the optimal mixture of decisions for end of life among various market segment over different IT equipment life cycles can be determined. (Noorbakhsh et al., 2015 ; Shokouhyar \& Aalirezaei., 2017)

\subsection{Future research}

1. This paper has presented a framework aiming at ranking effective Green IT criteria which contain mostly environmental aspects; However, it is suggested ranking Sustainable IT factors which is more extensive aspects containing economic and social perspectives.

2. So as to ranking Green IT factors, criteria have been considered independent in this study; applying other ranking methods such as ANP is suggested concerning existed correlation between criteria.

\subsection{Limitations}

Fuzzy AHP is a complex approach which needs too many numerical calculations in analysing combined preferences compared with the classic AHP. In addition, in AHP assumption there is no correlation between criteria which might be a drawback of AHP.

In AHP, although various approaches are utilized for defuzzification, each approach extracts different levels of information from the fuzzy numbers, therefore might give different ranking output, in this case, aggregation of preferences is not easily interpretable. Consequently, an alternative ranked the best may be ranked differently upon changing the defuzzification approach. This is called rank reversal or fuzzy reciprocals, which is a controversial debate in AHP method. This problem is further exacerbated with the fuzzy outputs and using different defuzzification techniques.

There are two general limitations regarding conducting qualitative meta-synthesis. First, there is a limitation of discerning or measuring the quality of qualitative research. It is important to recognize that qualitative research as a body of research is not as unified as quantitative research. There are significant differences in theoretical perspectives as well as differences in methodologies. A second issue of concern in conducting qualitative meta-synthesis is the critical context may be stripped away and the rich, thick description will be sacrificed.

\section{References}

Affanni, A., Bellini, A., Franceschini, G., Guglielmi, P., \& Tassoni, C. (2005). Battery choice and management for new-generation electric vehicles. IEEE Transactions on Industrial Electronics, 52(5), 1343-1349. 
Akman, I., \& Mishra, A. (2015). Sector diversity in Green Information Technology practices: Technology Acceptance Model perspective. Computers in Human Behavior, 49, 477486.

Anthony, B. J., \& Majid, M. A. (2016). Green IS for Sustainable Decision Making in Software Management. Journal of Soft Computing and Decision Support Systems, 3(3), 20-34.

Bai, C., \& Sarkis, J. (2013). Green information technology strategic justification and evaluation. Information Systems Frontiers, 15(5), 831-847.

Bose, R., \& Luo, X. (2011). Integrative framework for assessing firms' potential to undertake Green IT initiatives via virtualization-A theoretical perspective. The Journal of Strategic Information Systems, 20(1), 38-54.

Bozbura, F. T., \& Beskese, A. (2007). Prioritization of organizational capital measurement indicators using fuzzy AHP. International Journal of Approximate Reasoning, 44(2), 124-147.

Bramorski, T., Madan, M., Motwani, J., \& Sundarraj, R. P. (2000). Improving competitiveness of ready-to-assemble manufacturers through information technology. Logistics Information Management, 13(4), 201-209.

Buckley, J. J. (1985). Fuzzy hierarchical analysis. Fuzzy sets and systems, 17(3), 23

Capra, E., \& Merlo, F. (2009). Green IT: Everything starts from the software. ECIS 2009 Proceedings. 453.

Carlsson, C., \& Fullér, R. (1995, August). On fuzzy screening systems. In Proc. 3rd European Congress on Intelligent Technologies and Soft Computing, Aachen (pp. 1261-1264).

Chang, M. J. (2004). A study on software project risk management using fuzzy analytic hierarchy process. Master Thesis, National Pingtung University of Science and Technology, Department of Industrial Management (Chinese edition).

Chang, Y. H., \& Yeh, C. H. (2002). A survey analysis of service quality for domestic airlines. European Journal of Operational Research, 139(1), 166-177.

Choi, B. C., Shin, H. S., Lee, S. Y., \& Hur, T. (2006). Life cycle assessment of a personal computer and its effective recycling rate (7 pp). The International Journal of Life Cycle Assessment, 11(2), 122-128.

Chowdhury, G. G. (2015). How to improve the sustainability of digital libraries and information Services. Journal of the Association for Information Science and Technology.

Dao, V., Langella, I., \& Carbo, J. (2011). From green to sustainability: Information Technology and an integrated sustainability framework. The Journal of Strategic Information Systems, 20(1), 63-79.

Davidson, E., Vaast, E., \& Wang, P. (2011, September). The greening of IT: How discourse informs IT sustainability innovation. In IEEE 13th Conference on Commerce and Enterprise Computing (CEC), 2011 (pp. 421-427). IEEE.

Dolci, D. B., Lunardi, G. L., Salles, A. C., \& Alves, A. P. F. (2015). Implementation of green it in organizations: a structurational view. Revista de Administração de Empresas, 55(5), 486-497.

Dubey, R., Gunasekaran, A., Papadopoulos, T., \& Childe, S. J. (2015). Green supply chain management enablers: Mixed methods research. Sustainable Production and Consumption, 4, 72-88.

Erwin, E. J., Brotherson, M. J., \& Summers, J. A. (2011). Understanding qualitative metasynthesis: Issues and opportunities in early childhood intervention research. Journal of Early Intervention, 33(3), 186-200. 
Fernando, M. S. D. (2015). Green Information Technology Managerial Capabilities of IT Organizations in Sri Lanka. Scientific Research Journal (SCIRJ), Volume III.

Fitzsimmons, J., \& Fitzsimmons, M. (2013). Service management: Operations, strategy, information technology. McGraw-Hill Higher Education.

Frehe, V., \& Teuteberg, F. (2014). The Role of ICT in Green Logistics: A Systematic Literature Review. In Information Technology in Environmental Engineering (pp. 53-65). Springer Berlin Heidelberg.

Gan, L., Eskeland, G. S., \& Kolshus, H. H. (2007). Green electricity market development: Lessons from Europe and the US. Energy Policy, 35(1), 144-155.

Garbie, I. (2016). Sustainability Awareness. In Sustainability in Manufacturing Enterprises (pp. 131-150). Springer International Publishing.

Goasduff, L., \& Forsling, C. (2007). Gartner says 50 percent of mid and large sized western European IT organizations will develop a green strategy by the end of 2008. Gartner, Surrey.

Gordon, J., Skinner, A., \& Button, A. (2009). Green Technology: Driving Economic and Environmental Benefits from ICT. In World Economic Forum.

Hedman, J., \& Henningsson, S. (2016). Developing ecological sustainability: a green IS response model. Information Systems Journal.

Hilty, L. M., Arnfalk, P., Erdmann, L., Goodman, J., Lehmann, M., \& Wäger, P. A. (2006). The relevance of information and communication technologies for environmental sustainability-a prospective simulation study. Environmental Modelling \& Software, 21(11), 1618-1629.

Höjer, M., Larsen, K., \& Wintzell, H. (2012). Sustainable Communications and Innovation: Different Types of Effects from Collaborative Research Including University and Companies in the ICT-Sector. In ICT Critical Infrastructures and Society (pp. 170-182). Springer Berlin Heidelberg.

Hynes, M. (2013). What's smart about working from home? Telework and the sustainable consumption of distance in Ireland. In: Sylvie Thouësny, Cathy Fowley, Claire English (Eds.). Internet Research, Theory, and Practice: Perspectives from Ireland. Dublin: Research-Publishing.

Info Tech, (2007b). Exercise Environmentally Info Tech Research Group, October 22, pp. 19.

Info Tech, (2008). "Use EPEAT to Decrease Equipment Costs and Help the Environment", Info Tech Research Group, February pp.1-3.

Info Tech., (2007a). "PC Power Saving Plans Reduce Costs and Environmental Impact", Info Tech Research Group, December 19, pp.1-10.

Jenkin, T. A., McShane, L., \& Webster, J. (2011b). Green information technologies and systems: Employees' perceptions of organizational practices. Business \& Society, 50(2), 266-314.

Jenkin, T. A., Webster, J., \& McShane, L. (2011). An agenda for 'Green' information technology and systems research. Information and Organization, 21(1), 17-40.

Jenkin, T. A., Webster, J., \& McShane, L. (2011a). An agenda for 'Green' information technology and systems research. Information and Organization, 21(1), 17-40.

Jensen, L. A., \& Allen, M. N. (1996). Meta-synthesis of qualitative findings. Qualitative Health Research, 6(4), 553-560.

Kahraman, C., Cebeci, U., \& Ulukan, Z. (2003). Multi-criteria supplier selection using fuzzy AHP. Logistics Information Management, 16(6), 382-394. 
Kalpakjian, S., \& Schmid, S. (2006). Manufacturing, Engineering and Technology SI 6th Edition-Serope Kalpakjian and Stephen Schmid: Manufacturing, Engineering and Technology. Digital Designs.

Kant, K. (2009). Data center evolution: A tutorial on state of the art, issues, and challenges. Computer Networks, 53(17), 2939-2965.

KAYSON Inc., (2016) 'Rank 99 in Top 250 International Contractor (ENR)', retrieved 26 july 2016 [online]. http://www.kayson-ir.com/

Kipp, A., Jiang, T., Liu, J., Fugini, M., Vitali, M., Pernici, B., \& Salomie, I. (2012). Applying green metrics to optimize the energy-consumption footprint of it service centers. International Journal of Space-Based and Situated Computing 5, 2(3), 158174 .

Kipp, A., Jiang, T., Liu, J., Fugini, M., Vitali, M., Pernici, B., \& Salomie, I. (2012). Applying green metrics to optimize the energy-consumption footprint of it service centres. International Journal of Space-Based and Situated Computing 5, 2(3), 158-174.

Kittlaus, H. B., \& Krahl, D. (1998). The SIZ banking data Model. In Handbook on architectures of information systems (pp. 723-743). Springer Berlin Heidelberg.

M. Detyniecki, (2001). "Fundamentals on Aggregation Operators", Berkeley initiative in Soft Computing Computer Science Division University of California, Berkeley United Sates of America.

Manju, P., Minu, G. M., Jerusha, G. D., \& Banumathi, J. (2014). Li-Fi Technology Light Source as a Hub of Data Transmission and Projection Display. i-Manager's Journal on Embedded Systems, 3(4), 35.

Mansell, R., \& Wehn, U. (1998). Knowledge societies: Information technology for sustainable development. United Nations Publications.

Mines, C. (2008). The dawn of green IT services. Cambridge, MA: Forrester Research.

Mithas, S., Khuntia, J., \& Roy, P. K. (2010, December). Green Information Technology, Energy Efficiency, and Profits: Evidence from an Emerging Economy. In Proceedings of the International Conference on Information Systems (p. 11).

Molla, A., \& Abareshi, A. (2012). Organizational green motivations for information technology: empirical study. Journal of Computer Information Systems, 52(3), 92-102.

Molla, A., Cooper, V. A., \& Pittayachawan, S. (2009). IT and eco-sustainability: Developing and validating a green IT readiness model. In Proceedings of the International Conference on Information Systems, 141.

Molla, A., Cooper, V., \& Pittayachawan, S. (2011). The Green IT readiness (G-Readiness) of organizations: An exploratory analysis of a construct and instrument. Communications of the Association for Information Systems, 29(1), 67-96.

Moyer, J. D., \& Hughes, B. B. (2012). ICTs: Do they contribute to increased carbon emissions. Technological Forecasting and Social Change, 79(5), 919-931.

Mysore, Alka, (2012). Taxonomy of sustainable IT values. Graduate Theses and Dissertations. Paper 12588.

Noorbakhsh A, Shokohyar S and Aalirezaei A, (2015). Enhancing Economical, Environmental and Social Objectives through Leasing Services. Research Journal of Applied Sciences, Engineering and Technology, 11(10): 1124-1138.

Norton, M. J. (1996). Local Area Networks in Brief. Introducing and Managing Academic Library Automation Projects, 894(2986), 11.

Olson, E. G. (2008). Creating an enterprise-level "green" strategy. Journal of Business Strategy, 29(2), 22-30. 
Olzak, T., Sabovik, J., Boomer, J., \& Keefer, R. M. (2010). Microsoft virtualization: master Microsoft server, desktop, application, and presentation virtualization. Syngress.

Overby, S. (2007) Clean, Green Machines, CIO, 20, 12, 36-44

Ozturk, A., Umit, K., Medeni, I. T., Ucuncu, B., Caylan, M., Akba, F., \& Medeni, T. D. (2011). Green ICT (Information and Communication Technologies): a review of academic and practitioner perspectives. International Journal of eBusiness and eGovernment Studies, 3(1), 1-16.

Peng, F. (2013). Integration of TV White Space and Femtocell Networks (Doctoral dissertation, Queen Mary University of London).

Porter, M., \& Van der Linde, C. (1996). Green and competitive: ending the stalemate. Business and the Environment, 61-77.

Putri, n. K. S., \& Hudirarto, a. (2015). E-waste handling in dki jakarta private higher education institution. Journal Of Theoretical And Applied Information Technology, 74(2).

R. R. Yager, Aggregation operators and fuzzy systems modeling, Fuzzy Sets and Systems, 67 (1994), pp. 129-145.

Ruth, S. (2009). Green it more than a three percent solution. IEEE Internet Computing, 13(4), 74-78.

Saaty, T. L. (1980). The analytic hierarchy process. McGraw-Hill Inc.

Sharma, S., \& Sharma, G. (2016). A Review on Secure and Energy Efficient Approaches for Green Computing. International Journal of Computer Applications, 138(11).

Siegler, K., \& Gaughan, B. (2008). A practical approach to Green IT. Webinar. http://www.itmanagement.com/land/green-it-webinar/?tfso=2058 Retrieved August 2016.

Simmonds, D., \& Bhattacherjee, A. (2012). Environmental sustainability in organizations: The information technology role. AMCIS 2012 Proceedings. 11.

Sinha, M. (2011). Green information technology: a strategy to become socially responsible software organization. International Journal of Enterprise Computing And Business Systems, 1(2).

Shokouhyar, S., \& Aalirezaei, A. (2017). Designing a sustainable recovery network for waste from electrical and electronic equipment using a genetic algorithm. International Journal of Environment and Sustainable Development, 16(1), 60-79.

Stojanov, Zeljko, Vladimir Brtka, and Dalibor Dobrilovic. "Evaluation of the software maintenance tasks based on fuzzy screening." IEEE 11th International Symposium on Intelligent Systems and Informatics (SISY), IEEE, 2013.

Thomas, M., Costa, D., \& Oliveira, T. (2015). Assessing the role of IT-enabled process virtualization on green IT adoption. Information Systems Frontiers, 1-18.

Tomlinson, B. (2010). Greening through IT: information technology for environmental sustainability (pp. 1-28). Cambridge, MA: MIT Press.

Uddin, M., \& Rahman, A. A. (2012). Energy efficiency and low carbon enabler green IT framework for data centers considering green metrics. Renewable and Sustainable Energy Reviews, 16(6), 4078-4094.

Uddin, M., Hindu, R. C., Alsaqour, R., Shah, A., Abubakar, A., \& Saba, T. (2015). Knowledge management framework using green IT to implement sustainable entrepreneur ecosystem. Applied Mathematics \& Information Sciences, 9(5), 2703. 
Uddin, M., Talha, M., Rahman, A. A., Shah, A., Ahmed, J., \& Memon, J. (2012). Green Information Technology (IT) framework for energy efficient data centers using virtualization. International Journal of Physical Sciences, 7(13), 2052-2065.

Wang, X., Brooks, S., \& Sarker, S. (2015). Understanding Green IS Initiatives: A Multitheoretical Framework. Communications of the Association for Information Systems, 37(1), 32.

Wolf, F., \& Mujtaba, B. G. (2012). Sustainability in service operations. Implementation and Integration of Information Systems in the Service Sector, 257.

Yager, R. R. (1994). Aggregation operators and fuzzy systems modeling. Fuzzy sets and systems, 67(2), 129-145.

Zelenika, I., \& Pearce, J. M. (2014). Innovation through collaboration: scaling up solutions for sustainable development. Environment, Development and Sustainability, 16(6), 12991316.

Zhang, X., Chi, T., Chen, H., \& Zhao, H. (2003, July). Research on Electronic Government oriented geographic information service system. In Proceedings of the IEEE International Geoscience and Remote Sensing Symposium, (Vol. 6, pp. 3796-3798). IEEE

Copyright: (C) 2017 Shokouhyar, Noorbakhsh \& Aalirezaei. This is an open-access article distributed under the terms of the Creative Commons Attribution-NonCommercial 3.0 Australia License, which permits non-commercial use, distribution, and reproduction in any medium, provided the original author and AJIS are credited.

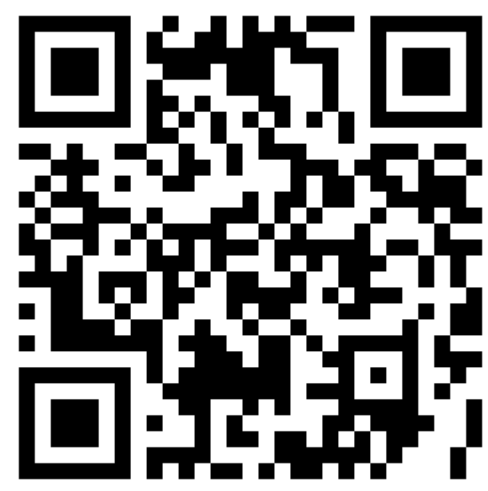




\section{Appendix}

\section{Pair-wise comparison of each Green IT criteria and sub-criteria}

\begin{tabular}{|l|r|r|r|r|}
\hline Goal & \multicolumn{1}{|c|}{ A } & \multicolumn{1}{c|}{ B } & \multicolumn{1}{c|}{ C } & Geometric Mean \\
\hline A & $(1,1,1)$ & $(1.413,2.056,2.631)$ & $(2.371,2.876,3.38)$ & $(1.496,1.808,2.072)$ \\
\hline B & $(0.38,0.486,0.708)$ & $(1,1,1)$ & $(1.76,2.268,2.773)$ & $(0.875,1.033,1.252)$ \\
\hline C & $(0.296,0.348,0.422)$ & $(0.361,0.441,0.568)$ & $(1,1,1)$ & $(0.474,0.535,0.621)$ \\
\hline Total & & & & $(2.845,3.377,3.945)$ \\
\hline
\end{tabular}

Table 12. Pair-wise comparison of Green IT main criteria

\begin{tabular}{|c|c|c|c|c|c|}
\hline B & b.1 & b.2 & b.3 & b.4 & $\begin{array}{l}\text { Geometric } \\
\text { Mean }\end{array}$ \\
\hline b.1 & $(1,1,1)$ & $(1.11,1.644,2.159)$ & $(1.413,1.933,2.446)$ & $(1.176,1.719,2.239)$ & $(1.165,1.529,1.854)$ \\
\hline b.2 & $(0.463,0.608,0.901)$ & $(1,1,1)$ & $(2.322,2.642,2.952)$ & $(2.322,2.642,2.952)$ & $(1.257,1.435,1.674)$ \\
\hline b.3 & $(0.409,0.517,0.708)$ & $(0.339,0.379,0.431)$ & $(1,1,1)$ & $(1.275,1.644,1.991)$ & (o.648,0.753,0.883) \\
\hline b.4 & $(0.447,0.582,0.85)$ & $(0.339,0.379,0.431)$ & $(0.502,0.608,0.784)$ & $(1,1,1)$ & $(0.525,0.605,0.732)$ \\
\hline Total & & & & & $(3.596,4.322,5.142)$ \\
\hline
\end{tabular}

Table 13. Pair-wise comparison of sub - criteria for recycling

\begin{tabular}{|l|r|r|r|r|r|}
\hline \multicolumn{1}{|c|}{ C } & \multicolumn{1}{|c|}{ c.1 } & \multicolumn{1}{c|}{ c.2 } & \multicolumn{1}{c|}{ c.3 } & c.4 & $\begin{array}{c}\text { Geometric } \\
\text { Mean }\end{array}$ \\
\hline C.1 & $(1,1,1)$ & $(1.431,1.815,2.169)$ & $(1.351,1.719,2.064)$ & $(1.496,2.041,2.569)$ & $(1.304,1.589,1.842)$ \\
\hline C.2 & $(0.461,0.551,0.699)$ & $(1,1,1)$ & $(0.944,1.351,1.719)$ & $(1.431,1.949,2.46)$ & $(0.888,1.098,1.311)$ \\
\hline C.3 & $(0.484,0.582,0.74)$ & $(0.582,0.74,1.059)$ & $(1,1,1)$ & $(2.789,3.291,3.792)$ & $(0.942,1.091,1.313)$ \\
\hline C.4 & $(0.389,0.49,0.668)$ & $(0.407,0.513,0.699)$ & $(0.264,0.304,0.359)$ & $(1,1,1)$ & $(0.452,0.526,0.64)$ \\
\hline Total & & & & & $(3.586,4.303,5.106)$ \\
\hline
\end{tabular}

Table 14. Pair-wise comparison of sub-criteria for reuse 


\begin{tabular}{|c|c|c|c|c|c|c|c|c|c|c|c|c|c|}
\hline $\mathbf{A}$ & a.1 & a.2 & a.3 & a.4 & a.5 & a.6 & a.7 & a.8 & a.9 & a.1o & a.11 & a.12 & $\begin{array}{c}\text { Geometric } \\
\text { Mean }\end{array}$ \\
\hline a.1 & $(1,1,1)$ & $\begin{array}{r}(1.351,1.864,2.3 \\
71) \\
\end{array}$ & $\begin{array}{r}(1.496,2.021,2 \\
537) \\
\end{array}$ & $\begin{array}{r}(1.465,1.838,2.1 \\
87) \\
\end{array}$ & $\begin{array}{r}(0.66,1.084,1.4 \\
65) \\
\end{array}$ & $\begin{array}{r}(0.944,1.465,1 . \\
974) \\
\end{array}$ & $\begin{array}{r}(1.176,1.552,1.9 \\
04) \\
\end{array}$ & $\begin{array}{r}(1.176,1.552,1.9 \\
04) \\
\end{array}$ & $\begin{array}{r}(1.351,1.922,2.4 \\
6) \\
\end{array}$ & $\begin{array}{r}(1.303,1.864,2 \\
395) \\
\end{array}$ & $\begin{array}{r}(1.176,1.683,2 \\
187) \\
\end{array}$ & $\begin{array}{r}(0.69,1.246,1.7 \\
77) \\
\end{array}$ & $\begin{array}{r}(1.114,1.554,1.95 \\
7) \\
\end{array}$ \\
\hline a.2 & $\begin{array}{l}\text { (0.422,o. } \\
536,0.74)\end{array}$ & $(1,1,1)$ & $\begin{array}{r}(1.552,2.15,2.7 \\
02)\end{array}$ & $\begin{array}{r}(0.758,1.303,1 . \\
825)\end{array}$ & $\begin{array}{r}(0.66,1.176,1.6 \\
83)\end{array}$ & $\begin{array}{r}(0.91,1.496,2.0 \\
41)\end{array}$ & $\begin{array}{r}(1.465,2.056,2 . \\
605)\end{array}$ & $\begin{array}{r}(0.944,1.351,1 . \\
719)\end{array}$ & $\begin{array}{r}(2.239,2.778,3 . \\
301)\end{array}$ & $\begin{array}{r}(2.141,2.678,3 . \\
201)\end{array}$ & $\begin{array}{r}(2.096,2.616,3 \\
129)\end{array}$ & $(0.5,1,1.5)$ & $\begin{array}{r}(1.063,1.512,1.9 \\
37)\end{array}$ \\
\hline a.3 & $\begin{array}{r}(0.394,0 . \\
495,0.66 \\
8) \\
\end{array}$ & $\begin{array}{r}(0.37,0.465,0.6 \\
44) \\
\end{array}$ & $(1,1,1)$ & $\begin{array}{r}(1.149,1.532,1.8 \\
88)\end{array}$ & $\begin{array}{r}(0.715,1.246,1 . \\
76)\end{array}$ & $\begin{array}{r}(0.871,1.443,1 \\
979)\end{array}$ & $\begin{array}{r}(1.024,1.552,2 . \\
064)\end{array}$ & $\begin{array}{r}(1.024,1.552,2 . \\
064)\end{array}$ & $\begin{array}{r}(0.66,1.176,1.6 \\
83)\end{array}$ & $\begin{array}{r}(0.758,1.303,1 \\
825)\end{array}$ & $\begin{array}{r}(1.683,2.208,2 \\
724)\end{array}$ & $(0.5,1,1.5)$ & $\begin{array}{r}(0.774,1.147,1.51 \\
9)\end{array}$ \\
\hline a.4 & $\begin{array}{r}\text { (0.457,0. } \\
544,0.68 \\
3 \text { ) } \\
\end{array}$ & $\begin{array}{r}(0.548,0.768,1 \\
32)\end{array}$ & $\begin{array}{r}(0.53,0.653,0.8 \\
71)\end{array}$ & $(1,1,1)$ & $\begin{array}{r}(1.516,2.038,2 . \\
551)\end{array}$ & $\begin{array}{r}(0.822,1.38,1.9 \\
08)\end{array}$ & $\begin{array}{r}(1.024,1.431,1.7 \\
97)\end{array}$ & $\begin{array}{r}(1.024,1.431,1.7 \\
97)\end{array}$ & $\begin{array}{r}(1.201,1.76,2.2 \\
9)\end{array}$ & $\begin{array}{r}(0.871,1.413,1 \\
933)\end{array}$ & $\begin{array}{r}(1.552,2.064,2 . \\
572)\end{array}$ & $(0.5,1,1.5)$ & $\begin{array}{r}(0.849,1.19,1.56 \\
2)\end{array}$ \\
\hline a.5 & $\begin{array}{r}(0.683,0 . \\
922,1.516 \\
) \\
\end{array}$ & $\begin{array}{r}(0.594,0.85,1.5 \\
16)\end{array}$ & $\begin{array}{r}(0.568,0.803,1.1 \\
398)\end{array}$ & $\begin{array}{r}(0.392,0.491,0 . \\
66)\end{array}$ & $(1,1,1)$ & $\begin{array}{r}(1.246,1.853,2 . \\
408)\end{array}$ & $\begin{array}{r}(1.351,1.736,2.0 \\
91)\end{array}$ & $\begin{array}{r}(1.176,1.431,1.6 \\
57)\end{array}$ & $\begin{array}{r}(0.822,1.351,1 \\
864)\end{array}$ & $\begin{array}{r}(0.944,1.496,2 \\
.021)\end{array}$ & $\begin{array}{r}(1.024,1.585,2 \\
114)\end{array}$ & $\begin{array}{r}(0.574,1.084,1 \\
589)\end{array}$ & $\begin{array}{r}(0.812,1.142,1.5 \\
7)\end{array}$ \\
\hline a.6 & $\begin{array}{r}\text { (0.506,0. } \\
683,1.059 \\
\text { ) }\end{array}$ & $\begin{array}{r}(0.49,0.668,1.0 \\
99)\end{array}$ & $\begin{array}{r}(0.505,0.693,1 . \\
149)\end{array}$ & $\begin{array}{r}(0.524,0.725,1 \\
217)\end{array}$ & $\begin{array}{r}(0.415,0.54,0.8 \\
03)\end{array}$ & $(1,1,1)$ & $(0.776,1.32,1.84$ & $\begin{array}{r}(1.024,1.431,1.7 \\
97)\end{array}$ & $\begin{array}{r}(0.944,1.351,1,1.7 \\
19)\end{array}$ & $(1,1.413,1.783)$ & $\begin{array}{r}(1.024,1.431,1 \\
797)\end{array}$ & $(0.5,1,1.5)$ & $\begin{array}{r}(0.684,0.963,1 \\
347)\end{array}$ \\
\hline a.7 & $\begin{array}{r}(0.525,0 . \\
644,0.85) \\
\end{array}$ & $\begin{array}{r}(0.384,0.486,0 . \\
683) \\
\end{array}$ & $\begin{array}{r}(0.484,0.644,0 \\
.977) \\
\end{array}$ & $\begin{array}{r}(0.556,0.699,0 \\
977) \\
\end{array}$ & $\begin{array}{r}(0.478,0.576,0 . \\
74) \\
\end{array}$ & $\begin{array}{r}(0.543,0.758,1 \\
289) \\
\end{array}$ & $(1,1,1)$ & $\begin{array}{r}(0.871,1.176,1.4 \\
31) \\
\end{array}$ & $\begin{array}{r}(1.351,1.79,2.16 \\
9) \\
\end{array}$ & $\begin{array}{r}(1.246,1.673,2 \\
048) \\
\end{array}$ & $\begin{array}{r}(0.758,1.303,1 . \\
825) \\
\end{array}$ & $(0.5,1,1.5)$ & $\begin{array}{r}(0.668,0.9,1.20 \\
3) \\
\end{array}$ \\
\hline a.8 & $\begin{array}{r}(0.525,0 . \\
644,0.85) \\
\end{array}$ & $\begin{array}{r}(0.582,0.74,1.0 \\
59) \\
\end{array}$ & $\begin{array}{r}(0.484,0.644,0 \\
.977) \\
\end{array}$ & $\begin{array}{r}(0.556,0.699,0 \\
977) \\
\end{array}$ & $\begin{array}{r}(0.603,0.699,0 \\
.85) \\
\end{array}$ & $\begin{array}{r}(0.556,0.699,0 \\
.977) \\
\end{array}$ & $\begin{array}{r}(0.699,0.85,1.1 \\
49) \\
\end{array}$ & $(1,1,1)$ & $\begin{array}{r}(1.552,1.941,2.2 \\
97) \\
\end{array}$ & $\begin{array}{r}(1.303,1.736,2 \\
112\end{array}$ & $\begin{array}{r}(0.758,1.303,1 \\
825) \\
\end{array}$ & $\begin{array}{r}(0.715,1.285,1 \\
825) \\
\end{array}$ & $\begin{array}{r}(0.725,0.944,1.2 \\
4) \\
\end{array}$ \\
\hline a.9 & $\begin{array}{r}(0.407,0 . \\
52,0.74) \\
\end{array}$ & $\begin{array}{r}(0.303,0.36,0.4 \\
47) \\
\end{array}$ & $\begin{array}{r}(0.594,0.85,1.5 \\
16) \\
\end{array}$ & $\begin{array}{r}(0.437,0.568,0 . \\
833) \\
\end{array}$ & $\begin{array}{r}(0.536,0.74,1.2 \\
17) \\
\end{array}$ & $\begin{array}{r}(0.582,0.74,1.0 \\
59) \\
\end{array}$ & $\begin{array}{r}(0.461,0.559,0 . \\
74) \\
\end{array}$ & $\begin{array}{r}(0.435,0.515,0 . \\
644) \\
\end{array}$ & $(1,1,1)$ & $\begin{array}{r}(1.084,1.465,1 \\
821) \\
\end{array}$ & $\begin{array}{r}(0.776,1.32,1.8 \\
4) \\
\end{array}$ & $\begin{array}{r}(0.574,1.084,1 . \\
589) \\
\end{array}$ & $\begin{array}{r}(0.561,0.746,1.0 \\
26) \\
\end{array}$ \\
\hline a.10 & $\begin{array}{r}\begin{array}{r}(0.418,0.0 \\
536,0.768 \\
)\end{array} \\
\end{array}$ & $\begin{array}{r}(0.312,0.373,0 \\
467)\end{array}$ & $\begin{array}{r}(0.548,0.768,1 \\
32)\end{array}$ & $\begin{array}{r}(0.517,0.708,1.1 \\
49)\end{array}$ & $\begin{array}{r}(0.495,0.668,1 . \\
059)\end{array}$ & $(0.561,0.708,1)$ & $\begin{array}{r}(0.488,0.598,0 . \\
803)\end{array}$ & $\begin{array}{r}(0.474,0.576,0 . \\
768)\end{array}$ & $\begin{array}{r}(0.549,0.683,0 \\
.922)\end{array}$ & $(1,1,1)$ & $\begin{array}{r}(0.891,1.431,1 \\
949)\end{array}$ & $\begin{array}{r}(0.574,1.084,1 . \\
589)\end{array}$ & $\begin{array}{r}(0.544,0.718,1.0 \\
01)\end{array}$ \\
\hline a.11 & $\begin{array}{r}(0.457,0 . \\
594,0.85) \\
\end{array}$ & $\begin{array}{r}(0.32,0.382,0.4 \\
77) \\
\end{array}$ & $\begin{array}{r}(0.367,0.453,0 \\
594) \\
\end{array}$ & $\begin{array}{r}(0.389,0.484,0 \\
.644) \\
\end{array}$ & $\begin{array}{r}(0.473,0.631,0 \\
977) \\
\end{array}$ & $\begin{array}{r}(0.556,0.699,0 \\
.977) \\
\end{array}$ & $\begin{array}{r}(0.548,0.768,1 . \\
32) \\
\end{array}$ & $\begin{array}{r}(0.548,0.768,1 \\
32) \\
\end{array}$ & $\begin{array}{r}(0.543,0.758,1 . \\
289) \\
\end{array}$ & $\begin{array}{r}(0.513,0.699,1 \\
122) \\
\end{array}$ & $(1,1,1)$ & $\begin{array}{r}(0.69,1.246,1.7 \\
77) \\
\end{array}$ & $\begin{array}{r}(0.511,0.672,0.9 \\
66) \\
\end{array}$ \\
\hline a.12 & $\begin{array}{l}\text { (0.563,o. } \\
803,1.45) \\
\end{array}$ & $(0.667,1,2)$ & $(0.667,1,2)$ & $(0.667,1,2)$ & $\begin{array}{r}(0.629,0.922,1 \\
741) \\
\end{array}$ & $(0.667,1,2)$ & $(0.667,1,2)$ & $\begin{array}{r}(0.548,0.778,1 \\
398) \\
\end{array}$ & $\begin{array}{r}(0.629,0.922,1.1 \\
741) \\
\end{array}$ & $\begin{array}{r}(0.629,0.922,1 \\
.741) \\
\end{array}$ & $\begin{array}{r}(0.563,0.803,1 \\
.45) \\
\end{array}$ & $(1,1,1)$ & $\begin{array}{r}(0.65,0.925,1.67 \\
7) \\
\end{array}$ \\
\hline Total & & & & & & & & & & & & & $\begin{array}{r}(8.953,12.415,17 \\
.006)\end{array}$ \\
\hline
\end{tabular}

Table 15. Pair-wise comparison of sub - criteria for reduction 